Sadmir KAROVIĆ, PhD*

Faculty of Law in Travnik, Assistant Professor of Criminal Law

State Investigation and Protection Agency,

Sarajevo
Review Scientific Article

Received:5 June 2020

Accepted:1 November 2020

UDK: 343.13(497.6)

https://doi.org/10.47152/rkkp.58.3.4

Marina M. SIMOVIĆ, PhD**

Secretary of the Ombudsman for

Children of the Republika Srpska

Faculty of Law, University Apeiron Banja Luka, Associate Professor

\title{
LEGAL NATURE AND MAIN PROCEDURAL DETERMINANTS OF CRIMINAL PROCEDURE IN BOSNIA AND HERZEGOVINA
}

In this paper, the authors analyse the legal nature of criminal procedure in Bosnia and Herzegovina, with the special emphasis on reform processes of criminal procedure legislation and adoption and acceptance of new legal solutions over the past two decades, acknowledging the aspiration for effectiveness and protection of basic human rights and freedoms. For the purpose of effective criminal procedure, it identifies the main and secondary actors in criminal proceedings whose role is crucial from the aspect of shedding light on and resolving a certain criminal matter, as well as issuing a judicial decision. To that end, the role and importance of those actors in taking procedural actions to carry out a criminal procedure task is emphasised for the purpose of understanding the legal nature, structure and course of the criminal

\footnotetext{
* e-mail: karovic.s@hotmail.com

** e-mail: vlado_s@blic.net
} 
procedure, and achieving the scope of legally prescribed rights of the suspect, that is, the defendant. In addition, special attention is paid to the specific procedural situation and status of an underage person in the criminal law as the perpetrator and injured parties in a criminal case, taking into account their age as the basis for the differentiation and protection in relation to adults.

\section{Key words: criminal procedure, criminal matter, actors in criminal proceedings, Bosnia and Herzegovina.}

\section{Legal nature of reform processes of criminal procedure laws in Bosnia and Herzegovina}

Intensive and dynamic processes in the criminal procedure laws in Bosnia and Herzegovina have over the past two decades focused primarily on several very important aspects among which we need to specifically emphasise the effectiveness of criminal proceedings, tendency to humanise the contemporary criminal procedure law, efficient and energetic fight against crime, and especially the specific forms of organised crime as the plague of the modern age (crimes in human trafficking, drug abuse, terrorism, economic and financial crime, cybercrime, etc.). In that regard, the question is posed even today if it is possible to imagine a human society without crime, which many prominent humanists and specialists in social sciences all give a negative answer to (Horvatić, Derenčinović, Cvitanović, 2016: 39). Apart from that, the continental - European system is sometimes denoted as inquisitorial, which is specifically characteristic of AngloSaxon authors of legal literature, while the Anglo-Saxon is denoted is accusatorial, but such terminology is basically incorrect, because even though the continental - European system contains certain inquisitorial elements, it is actually a mixed system, just like numerous Anglo-Saxon systems are no longer purely accusatorial (Stojanović, Škulić, Delibašić, 2018: 33).

With the general reform of the criminal procedure laws in Bosnia and Herzegovina from 2003, adoption and entry into force of the new criminal procedure codes at all levels ${ }^{1}$ brought about major or radical changes in criminal

1 Criminal Procedure Code of Bosnia and Herzegovina (Official Gazette of $\mathrm{BiH}, 3 / 03,32 / 03,36 / 03$, 26/04, 63/04, 13/05, 48/5, 46/06, 76/06, 29/07, 32/07, 53/07, 76/07, 15/08, 58/08, 12/09, 16/09, 93/09, 72/13, 65/18); Criminal Procedure Code of the Federation of Bosnia and Herzegovina (Official Gazette of FBiH, 35/03, 37/03, 56/03, 78/04, 28/05, 55/06, 27/07, 53/07, 09/09, 12/10, 08/13, 59/14); Criminal Procedure Code of the Republika Srpska (Official Gazette of RS, 53/12, 91/17, 66/18) and Criminal Procedure Code of the Brčko District of Bosnia and Herzegovina (Official Gazette of BDBiH, 10/03, 48/04, 06/05, 12/07, 14/07, 21/07, 27/14, 3/19). 
procedure primarily related to the acceptance and adoption of the new concept of investigation and an amended role of actors in criminal proceedings in the investigation, the simplification of the form of action, application of special investigative actions, etc. However, it is exactly the concept of investigation and the changed role of the actors in criminal proceedings (prosecutor's office, court) with a clearly defined accusation that the biggest changes refer to.

It is evident from the adoption and entry into force of the new concept of investigation in the criminal procedure laws of Bosnia and Herzegovina that the preliminary criminal investigation and preliminary proceedings are joined into a single investigation that is launched and carried out by the prosecutor. The prosecutorial concept which the scientific and expert community dubs the prosecutorial-police concept of investigation replaced the former judicial concept in the criminal procedure laws of the neighbouring countries too (Serbia, Croatia, Montenegro, North Macedonia), given the very proactive role of authorised officers in investigations, with the exception of Slovenia, where the judicial concept of investigation sustained certain modifications. On the other hand, the role of the court is passive when it comes to launching and conducting an investigation, as is the aspect of gathering evidence and conducting the investigation in its entirety, as well as the presentation of evidence, that is, defining the presence of a certain criminal offence and criminal responsibility.

Accordingly, respecting the accepted and adopted criminal procedure solutions from 2003, as a result of general reform, it is safe to conclude that the role of the court is passive and mainly controlling, and that it primarily refers to the control of legality with respect to immediate action of law enforcement agencies (prosecutor's office, police and other law enforcement agencies) and limitation of fundamental human rights and freedoms of the suspect or accused, this in the context of the application or performance of certain criminal procedure actions (presentation of evidence, special investigative actions, etc.). However, the limitation of freedom by prohibiting certain behaviours is justified only when such behaviours undoubtedly represent socially harmful behaviours (Stojanović, 2016: 38).

When it comes to secondary actors in criminal proceedings, the role of the defence counsel has been changed in relation to the former legal solutions, given that the new legal solutions allow the defence counsel to take certain actions from the moment of learning about a certain criminal investigation, establish all facts and gather evidence for the benefit of the accused, as well as all other actions in terms of the practical usage of securing the catalogue of rights to the accused. In addition, for the purpose of criminal prosecution, authorised officers as the secondary actor of the criminal proceedings, have a crucial and proactive role in 
criminal proceedings in terms of timely detecting criminal offences as the primary or basic police activity, as well as the investigative and the role of presenting evidence manifested as the practical realisation of orders and requests of the prosecutor's office and court as the main actors gathering the necessary evidence about a certain criminal offence and the accused or the defendant. The detection role of authorised officers is an initial activity necessary for the existence of reasonable grounds as a necessary condition for the prosecutor to launch and conduct an investigation with respect to the presence of the specific criminal offence (Karović, Orlić, 2020: 114).

Apart from the effectiveness of criminal proceedings which is the main interest of all reform processes not only in Bosnia and Herzegovina but in the neighbourhood and the region, it is important to emphasise a very prominent tendency for humanising the contemporary criminal procedure law from the aspect of the protection of fundamental human rights and freedoms of every individual, irrespective of their national, ethnic, religious or racial background. Analysing the valid legal provisions, it is evident that the position of the suspect or accused in a criminal proceeding in terms of the provision of their rights and freedoms has significantly improved as the right to defence is manifested in all stages of action for the purpose of shedding light on and resolving a certain criminal matter and making a proper judgement. The catalogue of rights and universal guarantees for the suspect or accused in the criminal proceeding is direct and practically implemented in terms of execution through the component of humanisation which is incorporated in a number of international legal documents as well. It can be concluded that the application of criminal repression by law enforcement actors or agencies with respect to the limitation of certain human rights and freedoms is conditioned by restrictive legal requirements and reduced to the smallest or proportionately necessary measure in order to satisfy the legally justified goal - an efficient and effective fight against crime. The wave of reform processes of the criminal procedure legislation over the past two decades has bypassed neither the neighbouring countries (countries of the former Yugoslavia), nor the regional countries, given the global processes at the international, global level regarding the definition and implementation of international standards at the level of execution including the position, status and treatment of the suspect or accused, especially a juvenile as the perpetrator, as well as an injured party in a criminal proceeding.

Development of the contemporary criminal procedure law which is still ongoing given that, by its destructive nature and consequences, and especially some new forms, crime requires due attention of legislators in terms of timely and proportionate amendments to the criminal procedure codes with respect to 
timely, efficient and legal detection, investigation and proving of crimes, as well as the prevention of crime in general. However, from the aspect of the rights of the injured party or victim as a secondary actor in a criminal proceeding, we may conclude that they are marginalised, knowing that the commitment of a certain crime jeopardises or violates a certain good (personal or property right) of the injured party themselves. This prompts a reasonable, justified and purposeful need for legislators in some future interventions in amending the laws to recognise the need for further improving the position, status and treatment of the injured party in terms of achieving their rights and remedying the harmful consequences.

\section{Specific position and status of a juvenile in the criminal legislation of Bosnia and Herzegovina}

Intensive and dynamic reform processes in Bosnia and Herzegovina, the neighbourhood and the region have especially become prominent when it comes to the development of the juvenile criminal law and adoption of certain international legal standards which determine the action of law enforcement actors or agencies with respect to this specific age group. It is exactly due to age as the core parameter or criterion that legislators have absolutely justifiably and purposefully recognised the need to isolate legal regulations, that is, provisions of the law from the general part of the law, thus accentuating the difference and different position, status and treatment of juveniles as opposed to adult perpetrators. With respect to the general form, the treatment of juveniles by its structure is not "defective," no stage or stadium is missing; rather, its structural elements are significantly modified in order to adjust the physiognomy of the procedure to the personality of the minor (Orlić, Pehlić, Tufekčić, 2019: 494). With the adoption and entry into force of the law on the protection and treatment of children and juveniles in criminal proceedings at the level of the entities ${ }^{2}$ and Brčko District $^{3}$ legal provisions related to the criminal position of minors have been isolated, which is significant progress. That is how the juvenile criminal law gains its independence and autonomy, even though these provisions related to

2 The Law on the Protection and Treatment of Children and Juveniles in the Criminal Procedure of the Federation of Bosnia and Herzegovina (Official Gazette of FBiH, 7/14) and Law on the Protection and Treatment of Children and Juveniles in the Criminal Procedure of the Republika Srpska (Official Gazette of RS, 13/10, 63/11, 61/13).

3 The Law on the Protection and Treatment of Children and Juveniles in the Criminal Procedure of the Brčko District of Bosnia and Herzegovina (Official Gazette of BDBiH, 53/11). 
juveniles at the state level are still contained in the general part of the Criminal Code of $\mathrm{BiH}^{4}$ and Criminal Procedure Code of $\mathrm{BiH}$.

On defining legal norms for the provisions related to the action of law enforcement actors or agencies, the legislators showed specific sensibility to juveniles and directed their attention to the use of certain terms for juveniles in order to prevent or make impossible the stigmatisation of juveniles as perpetrators of certain criminal offences. In terms of terminology too, the legislators avoided the usage of certain legal terms characteristic for adult perpetrators of crimes. Thus, the procedure against juveniles is not called "criminal" but "procedure against juveniles," unlike the general procedure conducted against suspects or accused persons (M. Simović, M. Simović, 2015: 26). On the other hand, action of law enforcement actors or agencies is conditioned by an appropriate specialisation of experts of various profiles with professional capability to respect the personality of juveniles in the broadest sense (e.g. conducting an interview, etc.). Hence, the legislators demonstrated a special feeling for juveniles as perpetrators, as well as the injured parties, that is, victims of a certain crime.

Juveniles as injured parties or victims of a certain crime require special protection so as to avoid their further, secondary victimisation. They require special attention given very prominent negative and long-term effects on the mental state of juveniles, especially when it comes to various forms of sexual exploitation (e.g. human trafficking crimes) where it is necessary to ensure appropriate help and support even after the conclusion of the proceedings. Namely, numerous pieces of research show that children who were victims of abuse get frustrated and get emotional scars, which is often a strong impulse for developing their own aggression and growing to abuse others (Škulić, 2011: 348).

One of the contemporary trends in criminal law, which is especially prominent when it comes to juveniles in conflict with the law is the encouragement of the development of alternative forms of response to delinquent behaviours by youth, which, apart from searching for alternatives to the institutional treatment, encompass also the efforts to try and resolve cases of juvenile delinquency outside criminal proceedings, and using the trial as ultima ratio for juvenile perpetrators of criminal offences (Gurda, 2011: 178). In that respect, a major novelty in treating juveniles in Bosnia and Herzegovina is the acceptance and introduction of alternative or different measures of diversion which are actually a replacement for repressive measures. It is their goal to divert the criminal proceeding and apply alternative (diversion) measures aiming to resocialize juveniles instead of punishing them.

4 Criminal Code of Bosnia and Herzegovina (Official Gazette of BiH, 3/03, 32/03, 37/03, 54/04, $61 / 04,30 / 05,53 / 06,55 / 06,32 / 07,8 / 10,47 / 14,22 / 15,40 / 15,35 / 18)$. 


\section{The main and secondary actors in criminal proceedings}

Respecting the statutory legal status, actors in criminal proceedings as legal or natural persons do not have the same procedural position or significance from the aspect of commencing, conducting and finalising the criminal proceedings. Given the procedural position and significance, we may divide actors in criminal proceedings into main and secondary. The main actors in criminal proceedings are: The court (independent and autonomous state authority performing the function of trial), the prosecutor (function of criminal prosecution) and the suspect or accused (function of defence) without whom it is impossible to initiate, conduct or finalise the criminal proceedings. The secondary actors in criminal proceedings are the injured parties, a legal or natural person and the body of guardianship.

The procedural roles of the main and secondary actors in criminal proceedings differ and are achieved or ensured exclusively on the basis of a consistent application of the legal provisions regulating and establishing the norms for their roles in criminal proceedings. Nevertheless, the significance of the main actors in criminal proceedings is primarily formal and procedural given that without a prosecutor it is not possible to initiate an investigation, issue an indictment or act as a legal representative before the court; without the suspect or accused there would be no one to prosecute, and without the court there would be no one to issue the decision (Halilović, 2019: 110).

It is primarily the criminal and legal nature of the concept of investigation that the role of actors in criminal proceedings and the position of the prosecutor in the investigation in the context of their jurisdiction depends (Karović, 2019: 67). Regarding the launch and conduct of criminal proceedings, the prosecutor appears as the only legal authority who can in every specific case autonomously assess whether there are grounds to suspect that a certain criminal offence has been committed (a substantive condition). Practically, without the prosecutor it is impossible to imagine launching and conducting an investigation regardless of whether they autonomously carry out their prosecutorial assessment and make a decision ordering an investigation. In addition, the acting prosecutor leads the investigation and has a supervisory role in relation to the authorised officers regarding the performance of certain criminal procedure actions. To that effect, they make an autonomous decision about the selection of criminal procedure actions (evidentiary proceedings, special investigative actions) which have to be applied in every specific criminal case, depending on the nature of a certain criminal offence, the way it was committed and other criminal procedure specificities which directly determine the entire procedure.

The prosecutor has the right and duty to: a) immediately upon learning there are grounds to suspect that a criminal offence was committed, take the necessary 
measures to detect it and conduct an investigation, find the suspect, manage and supervise the investigation, and manage the activities of authorised officers including finding the suspect and collecting statements and evidence, b) conduct an investigation in line with this law, c) grant immunity in accordance with the law, d) request information from state bodies, enterprises, legal and natural persons in Bosnia and Herzegovina, e) issue summons and orders and suggest the issuance of summons and orders in accordance with the law, f) order the authorised officer to carry out the order issued by the court in accordance with the law, g) establish the facts required for settling a property claim and seizing of property gain obtained through criminal offence in accordance with the law, $h$ ) propose the issuance of a warrant in accordance with the law, i) issue and defend the indictment before the court, j) submit legal remedies, $\mathrm{k}$ ) perform other duties prescribed by the law (Article 35, para 2 of the Criminal Procedure Code of Bosnia and Herzegovina).

One of the main actors in criminal proceedings is the suspect or accused, as a natural or legal person. The position of the suspect or accused in the law depends on the stage of the proceeding, provided that they are always an actor and party in the proceeding (M. Simović, V. Simović, 2011: 116). In Article 20 of the Criminal Procedure Code of Bosnia and Herzegovina, the legislator defines, that is, determines the meaning of these terms in the catalogue of the basic terms of this law. The suspect is a person with respect to whom there are grounds for suspicion that the person may have committed a criminal offence. ${ }^{5}$ The accused refers to a person against whom one or more counts in an indictment have been confirmed. ${ }^{6}$

The suspect or accused in criminal proceeding performs the function of defence. Practically, the function of defence is achieved by undertaking certain procedural actions to refute the charges. There are also procedural actions of negating the presence of a criminal offence and criminal responsibility, where facts are presented and evidence proposed in favour of the person against whom the criminal proceeding is held, and such procedural actions are also functionally related and make up the function of defence (Stanojević, Ignjatović, 2007: 70).

It is possible for the prosecutor to launch and conduct an investigation against an unknown person as well but, on the other hand, it is impossible to issue an indictment without defining the identity of the person the indictment refers to. As regards the procedural status of the suspect or accused, it is compatible with the standard of proof, that is, the degree of suspicion in the commitment of a certain criminal offence. The status of the suspect exists when the standard of proof of grounds to suspect that a certain criminal offence has been committed is

5 Article 20, item a) of the Criminal Procedure Code of Bosnia and Herzegovina.

6 Article 20, item b) of the Criminal Procedure Code of Bosnia and Herzegovina. 
met, unlike the procedural status of the accused for which it is necessary to meet a greater degree of suspicion that a certain criminal offence has been committed, and that is reasonable grounds.

For the purpose of achieving the protection of citizens from ungrounded or unlawful action in terms of the violation or threat to the fundamental human rights and freedoms, that is, the disrespect of the axiom of legal security, the criminal procedure code stipulates certain guarantees for the suspect or accused in criminal proceedings. In addition, this law also stipulates a catalogue of rights for all persons with the procedural status of the suspect or accused in criminal proceedings. However, aside from the universal guarantees and rights of the suspect or accused, certain obligations in criminal proceedings are also stipulated (the subject of proof, response to court, compliance with the court and procedural discipline).

The court is an independent and autonomous state authority performing the function of adjudication. The criminal court appears within the courts of general jurisdiction over criminal jurisdiction, that is, the judicial function in criminal matters (Jekić, Škulić, 2005: 47). Given the accusatorial principle, the concept of investigation and legal nature of criminal proceedings in Bosnia and Herzegovina as a compact whole, the role of the court is passive and mainly refers to the aspect of actions of the preliminary proceedings judge who, on the basis of their competences, controls the legality of establishing and adjudicating on the justification of the application or performance of certain criminal procedure actions by law enforcement agencies (prosecutor's office, police and other law enforcement agencies) limiting the fundamental human rights and freedoms (evidence gathering, special investigative actions). In addition, the court is very passive in terms of evidence given that the presentation of evidence is generally left to the parties (the prosecutor and the defendant, that is, the defence counsel), while the court ultimately issues a judicial decision (judgement) on the basis of an autonomous assessment.

Apart from the main actors, an important role in shedding light on and resolving a certain criminal matter is that of secondary actors in criminal proceedings. One of the main secondary actors in criminal proceedings is the injured party, that is, the victim of the committed criminal offence. The Criminal Procedure Code defines the procedural status of the injured part in criminal proceedings, while the term victim is used in victimology, criminology, psychology, substantive criminal law, and other social sciences. As a rule, the injured party appears as a witness given that their personal or property right is violated or jeopardised by a certain criminal offence.

The defence counsel also appears in the function of defence and achievement of the catalogue of statutory rights of the suspect or accused. It is practically 
impossible to imagine the function of defence in criminal proceedings without an active participation of the defence counsel in carrying out formal defence. The suspect or accused may not exercise the right to defence by themselves regardless of the fact it is a person who is the immediate actor or witness of a certain criminal event. The defence counsel creates operational tactics and defence strategy in every specific case, and with their participation directly allows for taking proportionately necessary procedural actions in using the right to defence by the suspect or accused in all stages of criminal proceedings.

In terms of the timely detection, investigation and proving of criminal offences, the primary role and significance is that of authorised officers. The primary or main activity of authorised officers is the detection of criminal offences, and timely reporting to the prosecutor's office on the existence of grounds to suspect that the crime was committed. Furthermore, in the prosecutorial-police concept of investigation, major activities concerning the gathering of evidence are entrusted with authorised officers in particular, under the managing and supervisory role of the acting prosecutor. Authorised officers are an operative service of a kind to the prosecutor's office in terms of carrying out its orders and requests for the performance of appropriate investigative actions and evidencegathering. In terms of establishing the presence of a certain criminal offence and individual criminal responsibility, authorised officers very often appear as witnesses in the presentation of evidence at the proposal of the prosecutor, regarding the circumstances of taking certain investigative actions and gathering evidence (evidentiary proceedings, special investigative actions, etc.).

A very important role in shedding light on and resolving a certain criminal matter is that of expert witnesses too. When it is necessary to establish certain important facts, which are directly related to a certain criminal matter, expert witnesses are engaged, who with their expert knowledge, skills and competences from a certain scientific field provide their findings and opinions which allow the prosecutor and court to issue a correct court decision.

Significant is also the role and participation of legal representatives, judicial associates, witnesses, experts, etc.

\section{Definition of a certain criminal matter and standards of proof}

The main subject of criminal proceedings is a certain criminal matter which is directly and closely tied to and conditioned by the standards of proof which make the basis for the definition and differentiation of the criminal matter in a 
proper sense and the criminal matter in an improper sense. However, aside from the criminal matter as the main subject of criminal proceeding, other issues may also be reviewed and adjudicated upon in such proceedings which are part of the secondary elements of criminal procedure, as follows: property claim, procedural costs and preliminary issues.

With the adoption and entry into force of the new criminal procedure codes in Bosnia and Herzegovina, the prosecutorial concept of investigation which minimises the degree of suspicion necessary for launching and conducting an investigation has been accepted. Namely, in order to launch and conduct an investigation, that is, to issue an order for conducting an investigation by the acting prosecutor, it is necessary to meet the lowest degree of suspicion or likelihood that a certain criminal offence has been committed, and that is reasonable grounds. In cases like this, when the legally prescribed standard of grounds to suspect that a certain criminal offence has been committed is met, it is automatically a criminal matter in an improper sense. Thus, reasonable grounds are the lowest level of likelihood that a certain criminal offence has been committed by a certain person and therefore, there is a criminal matter in an improper sense when this standard of proof is met. However, for the criminal matter to exist in a proper sense, it is necessary to meet a higher degree of suspicion that a certain criminal offence has been committed by a certain person, and that is grounded suspicion. Criminal matter in a proper sense exists when there is grounded suspicion, when there are facts and circumstances justifying the suspicion that a certain person has committed a certain criminal offence (Bejatović, 2019: 29).

The presence of the standard of proof of grounded suspicion that a certain person has committed a certain criminal offence makes obligatory the presence or the provision of necessary evidence collected in the investigation from which the standard of proof derives, which is confirmed by the presence of the objective and subjective features of the body of the specific criminal offence. Such differentiation of criminal matter in the criminal matter in a proper and the criminal matter in an improper sense is justified and purposeful since the presence of the criminal matter in an improper sense which is conditioned by the presence of the lowest level of likelihood that a certain criminal offence has been committed or the standard of proof of reasonable grounds does not necessarily mean that it will "turn into" a criminal matter in a proper sense after the investigation because the investigation may also be terminated by suspension. Reasonable grounds are a standard of proof in criminal proceedings which needs to be met for the acting prosecutor to draft and issue an indictment and then for the preliminary proceedings judge to uphold it, in which case it is a criminal matter in a proper sense. 


\section{Conclusion}

The overall development of criminal procedure in Bosnia and Herzegovina over the past two decades has resulted in the adoption and acceptance of certain new legal solutions of procedural nature characteristic of the AngloSaxon legal tradition, therefore in major amendments to the criminal procedure, especially in terms of investigation where the role of actors in criminal proceedings of the prosecutor's office and court has evidently been changed. The prosecutorial and prosecutorial-police concept of investigation, which replaced the former judicial concept of investigation, recognises the prosecutor as the only legal authority authorised to launch and conduct an investigation, while the role of the court is passive and mainly refers to the control function of the preliminary hearing judge related to the limitation of human rights and freedoms of the suspect or accused (issuing orders for certain evidence gathering and special investigative actions).

The complexity of establishing the presence of a certain criminal offence and criminal responsibility is either directly or indirectly manifested through activities of the main and secondary actors in criminal proceedings, given that restrictive legal requirements have to be met in every specific criminal case. Evidentiary hearing is a "duel" between two opposing sides (parties), on the one hand the prosecutor on the side of the prosecution, and on the other the suspect or accused on the side of the defence. The role of the court is mainly passive.

The issue of an efficient criminal procedure and adequacy of the state reaction to crime has to be observed from the aspect of professional capability, procedural discipline and personal professional responsibility and interest of the persons entrusted with certain public powers in terms of consistent enforcement of the law. It has to be pointed out that the burden of proof lies with the acting prosecutor, as well as authorised officers who directly gather evidence upon which depends the outcome of the criminal proceeding and issuance of the judicial decision. Acquittals in certain criminal cases, most often due to the lack of evidence or some other procedural reasons, and especially in case of specific forms of organised crime, produce very negative reaction of the scientific and general public. It represents an extra burden, professional challenge and responsibility for the acting prosecutor in terms of conducting an efficient investigation and gathering the necessary evidence, issuing and defending the indictment, presenting evidence, as well as acting in line with legal remedies. On the other hand, the court has a passive, yet very important and responsible role from the aspect of issuing a correct judicial decision (judgement) which sheds light on a certain criminal matter and ultimately resolves it. 


\section{Literature}

- Bejatović, S. (2019) Krivično procesno pravo, drugo izmenjeno i dopunjeno izdanje. Beograd: Službeni glasnik.

- Gurda, V. (2011) Odgojne preporuke kao alternativa krivičnom postupku prema maloljetnicima i njihova primjena u praksi. Anali Pravnog fakulteta $u$ Zenici, 5(8), pp. 177-199.

- Halilović, H. (2019) Krivično procesno pravo. Knjiga prva: Uvod i temeljni pojmovi. Sarajevo: Fakultet za kriminalistiku, kriminologiju i sigurnosne studije, Univerzitet u Sarajevu.

- Horvatić, Ž., Derenčinović, D., Cvitanović, L. (2016) Kazneno pravo, Opći dio 1, Kazneno pravo i kazneni zakon. Zagreb: Pravni fakultet Sveučilišta u Zagrebu.

- Jekić, Z., Škulić, M. (2005) Krivično procesno pravo. Istočno Sarajevo: Pravni fakultet, Univerzitet u Istočnom Sarajevu.

- Karović, S. (2019) Krivičnoprocesna uloga i položaj tužioca u istrazi u Bosni i Hercegovini (I dio). IP Glosarijum Beograd, (2).

- Karović, S., Orlić, S. (2020) Otkrivačka, istražna i dokazna uloga ovlaštenih službenih lica u kaznenom postupku Bosne i Hercegovine. Policija i sigurnost, 29(1-2).

- Orlić, S., Pehlić, I., Tufekčić, N. (2019) Maloljetničko prestupništvo. Zenica: Islamski pedagoški fakultet.

- Simović, M., Simović, M. (2015) Maloljetnici u kaznenom zakonodavstvu Bosne i Hercegovine. Sarajevo: Fineks.

- Simović, M., Simović, V. (2011) Krivično procesno pravo, četvrto izdanje (izmijenjeno i dopunjeno). Banja Luka: Pravni fakultet PIM Univerziteta u Lukavici.

- Stanojević, P., Ignjatović, A. (2007) Krivično procesno pravo. Novi Sad: Pravni fakultet u Novom Sadu.

- Stojanović, Z. (2016) Politika suzbijanja kriminaliteta. Beograd: Pravni fakultet, Univerzitet u Beogradu.

- Stojanović, Z., Škulić, M., Delibašić, V. (2018) Osnovi krivičnog prava, Krivično procesno pravo - Krivični postupak kroz praktičnu primenu - knjiga 2. Beograd: Službeni glasnik.

- Škulić, M. (2011) Maloletničko krivično pravo. Beograd: Službeni glasnik i Pravni fakutet, Univerzitet u Beogradu.

Laws:

- Criminal Code of Bosnia and Herzegovina, Official Gazette of BiH, No. 3/03, 32/03, 37/03, 54/04, 61/04, 30/05, 53/06, 55/06, 32/07, 8/10, 47/14, 22/15, $40 / 15,35 / 18$. 
- Criminal Procedure Code of Bosnia and Herzegovina, Official Gazette of BiH, No. 3/03, 32/03, 36/03, 26/04, 63/04, 13/05, 48/5, 46/06, 76/06, 29/07, 32/07, 53/07, 76/07, 15/08, 58/08, 12/09, 16/09, 93/09, 72/13, 65/18.

- Criminal Procedure Code of the Brčko District of Bosnia and Herzegovina, Official Gazette of BDBiH, No. 10/03, 48/04, 06/05, 12/07, 14/07, 21/07, 27/14, 3/19.

- Criminal Procedure Code of the Federation of Bosnia and Herzegovina, Official Gazette of FBiH, No. 35/03, 37/03, 56/03, 78/04, 28/05, 55/06, 27/07, 53/07, 09/09, 12/10, 08/13, 59/14.

- Criminal Procedure Code of the Republika Srpska, Official Gazette of RS, No. 53/12, 91/17, 66/18.

- The Law on the Protection and Treatment of Children and Juveniles in the Criminal Procedure of the Brčko District of Bosnia and Herzegovina, Official Gazette of BDBiH, No. 53/11.

- The Law on the Protection and Treatment of Children and Juveniles in the Criminal Procedure of the Federation of Bosnia and Herzegovina, Official Gazette of FBiH, No. 7/14.

- The Law on the Protection and Treatment of Children and Juveniles in the Criminal Procedure of the Republika Srpska, Official Gazette of RS, No. 13/10, 63/11, 61/13. 